УДК 81.111: 81'37

DOI: $10.24144 / 2617-3921.2019 .17 .171-181$

Галина Онищак кандидат філологічних наук, старший викладач кафедри англійської філології ДВНЗ «УжНУ» https://orcid.org/0000-0002-5133-4313 Ужгород, Україна, +38(099) 04177 63, halyna.onyshchak@uzhnu.edu.иа

\title{
Лексико-семантична група «Добро» як фрагмент мовної картини світу англійців
}

Анотаиія. Стаття присвячена дослідженню засобів вербалізаџї добра в сучасній англійській мові, яке проводиться за допомогою методики формалізованого аналізу лексичної семантики на матеріалі суиільного аналізу лексикографічних джерел. Комплексне дослідження лексикосемантичної групи "Добро» як фрагмента мовної картини світу англійців дало змогу виявити суттеві якісні й кількісні характеристики лексичних одиниць на позначення добра та їхні семантичні особливості.

Ключові слова: вербалізація, формалізований аналіз, лексикосемантична група, фрагмент мовної картини світу, лексична одиниия, якісні й кількісні характеристики.

Abstract. The article deals with the problem of good verbalization in modern English. The differences between conceptual and language world pictures have been considered. The complex study of the lexico-semantic group "Good» as a fragment of English language world picture by means of the procedure of formalized lexical semantics' analysis has given the possibility to single out its essential qualitative and quantitative characteristics, and structural semantic peculiarities. The lexico-semantic group of the nouns denoting good in modern English is of complex and multicomponential structure. Both the order and organization of the lexical stock under study are hierarchical. The latter is divided into the following groups: lexical units with the highest, middle, low degrees of polysemy and monosemantic words.

The analysis made has shown that the nouns denoting good occupy an important place within English lexical system and they are regarded as philosophical concepts of the world perception being an integral part of the humanity and human nature. Therefore, they make up the broadest and leading paradigm of valuable moral orientation, knowing no boundaries of time and space and making the formula of our thinking and world perception. 
Keywords: verbalization, conceptual and language world pictures, lexicosemantic group, the procedure of formalized lexical semantics' analysis, qualitative and quantitative characteristics, lexical stock.

\section{Вступ}

У лінгвістиці кінця XX - початку XXI століття дослідницькі пріоритети і підходи зміщуються в антропоцентричну площину, де мова розглядається як «феномен людської психіки та менталітету у взаємодії з об'єктивною дійсністю» [5, с. 5]. Людський чинник та інтерпретація пізнавальної діяльності людини, спрямованої на вивчення об'єктивної дійсності, займають провідне місце в працях багатьох вітчизняних та зарубіжних лінгвістів (Ф.С. Бацевича, А. Вежбицької, І.О. Голубовської, М.П. Кочергана, М.П. Фабіан та ін.). Однак картина світу, сконструйована свідомістю окремої людини 3 урахуванням iii індивідуальних та національно-культурних особливостей, безумовно має суб'єктивний характер.

Мова, виступаючи «дзеркалом культури» [16, с. 14], відображає не тільки «реальний світ (точніше, його фрагмент, даний етносові в безпосередньо-чуттєвому сприйнятті), а також колективну етнічну свідомість, яка зберігає досвід попередніх поколінь і відбиває реальний світ у поступальному процесі пізнання» [3, с. 29]. Будь-яка мова $є$ унікальною структурною системою елементів, які позначають світобачення по-своєму за допомогою значень та асоціацій і виражається мовними засобами.

Розробка проблематики картини світу в різних гуманітарних галузях знання дає можливість усвідомити процеси сприйняття та інтерпретації культурно значущої інформації, взаємодії носіїв різних мов, принципи формування системи моральних, етичних та суспільних цінностей, установок, норм поведінки тощо. У лінгвістиці під «картиною світу» розуміють упорядковану сукупність знань про дійсність, яка формується у суспільній, груповій та індивідуальній свідомості [10, с. 10].

\section{1. Типологія картин світу.}

Картини світу надзвичайно різноманітні й характеризуються певною історичною, національною та соціальною детермінованістю. До основних характеристик картини світу психологи відносять її предметність, цілісність, структурність, константність i категоріальність. Виступаючи ядром світобачення, вона $\epsilon$ космологічно орієнтованою (є глобальним образом світу), водночас будучи антропоморфічною (несе в собі риси специфічного людського способу пізнання світу) [8, с. 347].

Розмежування «мовної картини світу / наївної» і «концептуальної картини світу / наукової» пов'язане із принципами інтерпретації об'єктивної дійсності. Першу відмежовують від концептуальної, або когнітивної моделі 
світу, що є основою мовного втілення, словесної концептуалізації сукупності знань людини про світ [7, с. 46]. Якщо наукова картина світу породжена науковою свідомістю і має схильність до об'єктивного осмислення реального світу, то мовна картина світу набуває суб'єктивного характеру, оскільки є результатом конструювання дійсності «наївною» свідомістю, яка пропускає навколишній світ крізь уявлення певного етносу, його історично напрацьований національний досвід тощо. Варто відзначити, що межі концептуальної картини світу значно ширші за межі мовної. Остання покриває певну, визначену частину першої, вербалізуючи далеко не все 3 того, що ми сприймаємо, оскільки є інші засоби вираження, такі як живопис, музика, архітектура, етикет, що $є$ невербальними засобами реалізації концептуальної картини світу [1, с. 87].

Порівняно 3 науковою картиною світу, яка перебуває в постійній динаміці із-за змін наукової думки, мовна картина світу змінюється дуже повільно, зберігаючи фрагменти наївного знання про світ. Останню трактують як «мозаїкоподібну польову структуру взаємопов'язаних мовних одиниць, що через складну систему фонетичних явищ, лексико-семантичних i граматичних значень, а також стилістичних характеристик відбиває відносно об'єктивний стан речей довкілля і внутрішнього світу людини» $[4$, c. 15], тобто мовна картина світу існує у вигляді значень мовних знаків, які утворюють сукупний семантичний простір мови $[11$, с. 6]. Під останнім розуміють сукупність одиниць, які називають елементи картини світу, яка склалася певним етносом у процесі його буття і визначає національнокультурну специфіку побудови і реалізації асоціативно-вербальної мережі ії мовних значень [12, с. 84].

Таким чином, концептуальна та мовна картини світу взаємопов'язані, хоча й мають певні відмінності. Обидві формують загальну картину світу й обумовлюють одна одну, адже зміни в знаннях про навколишній світ призводять до змін в їхньому осмисленні на рівні мовної свідомості. Концептуальна картина світу - це система уявлень, знань людини про об'єктивний світ, а мовна - ментальне відображення культурного досвіду нації та його вербальне уособлення. Обидві картини світу різняться елементами змісту: мовна визначається семантичними категоріями та полями, а концептуальна - поняттями та групами.

Актуалізований у мові спосіб концептуалізації світу частково універсальний і національно-специфічний. Специфіка національних мов і свідомості зумовлена змістом і способом діяльності людини, природними та соціальними умовами, матеріальною та духовною культурою, що фіксуються на різних мовних рівнях. Отже, мова - явище універсальне і піддається впливу з боку будь-яких змін в усіх сферах суспільного життя та тісно пов'язана з менталітетом, культурою і традиціями ії носіїв.

У сучасному мовознавстві етнічно обумовлене осмислення та оцінювання зовнішнього світу, актуалізоване в мовних формах, отримало 
назву національно-мовної картини світу. Вона $\epsilon$ синтетичною єдністю суб'єктивного і об'єктивного у світогляді людини, синтезуючи духовноіндивідуальні та культурно-історичні особливості розвитку етносу. Слушною $\epsilon$ думка I.O. Голубовської, яка розглядає національно-мовну картину світу як «виражене засобами певної мови світовідчуття і світорозуміння етносу, вербалізовану інтерпретацію мовним соціумом навколишнього світу і себе самого в цьому світі» [3, с. 6]. Виникнення національно-специфічних мовних форм визначається двома чинниками: 1) фактами зовнішнього світу стосовно етносу (природа та матеріальна культура народу, які етнос безпосередньо сприймає); 2) факторами національного способу мислення та менталітету [13, c. 243].

Сутність мовної картини світу $\epsilon$ антропоцентричною, адже вона передає не лише образ світу сам по собі, а й фіксує правила орієнтації людини у світі, формує стереотипи сприйняття, відображає накопичений досвід людства, обумовлює комунікативну поведінку, розуміння зовнішнього i внутрішнього світу людини. Завдяки мові людина виражає і пізнає саму себе, при цьому перша виступає «ментальним дзеркалом» національнокультурних цінностей. У зв'язку з цим, актуальними видаються дослідження не тільки «мовного індивіда» як об'єкта науки про мову, але й універсальних людських цінностей, тих «вічних» понять, якими виступають добро та зло, адже цінність $є$ тією категорією, що властива лише людині, яка здатна визначити, що для неї є добром, а що - злом, і встановити ціннісні орієнтири [9, с. 9]. Картина світу містить оцінні елементи навколишньої дійсності, осмислені людською свідомістю на основі як життєвого (індивідуального), так і суспільного (колективного) досвіду, а тому мовна картина світу $\epsilon$ наслідком діяльності цілого ряду поколінь. У цьому відношенні, мова виступає не стільки засобом пізнання світу, як засобом передачі досвіду світосприйняття.

\section{2. Лексична семантика як спосіб структурування уявлень про світ.}

Оскільки система цінностей охоплює як загальнолюдські, так i національно обумовлені цінності, особливого значення набуває проблема взаємовідношення національного та глобального, актуалізуються питання про ціннісні основи сучасної цивілізації, і як наслідок, дослідження категорії «добро» як фрагмента мовної картини світу англійців. У семантиці слів на позначення добра концентрується не тільки практичний досвід людини, але й уявлення про цінності, відповідність нормам, загальноприйнятим стандартам, тобто воно виступає елементом ціннісної картини світу спільноти. Добро можна віднести до універсальних понять, адже воно відіграє важливу роль у визначенні інших понять (моральність, справедливість, честь, гідність тощо) та лексикалізується у всіх мовах [2, c. 191]. У англійській мовній системі, окрім загальнолюдського 
(універсального), воно містить: а) національно-культурний (зумовлений проживанням особи у певному культурному оточенні); б) соціальний (пов'язаний 3 приналежністю до певного соціального стану); в) індивідуально-особистісний (сформований під впливом освіти, набутого досвіду, психофізіологічних особливостей, манери виховання тощо) компоненти.

Зазвичай, мовна картина світу досліджується на основі лексики, позаяк «саме в лексиці приховані фундаментальні риси мовної структури, які зумовлюють наявність багатьох специфічних ознак на інших рівнях мови» $[6$, c. 88], а «опора на семантику сприятиме розкриттю максимально широкої сукупності системно зумовлених структурних характеристик мови, що в свою чергу дасть змогу пролити світло на проблему взаємовідношення мови і мислення» [6, с. 88]. Саме тому досліджуваний фрагмент мовної картини світу трактуємо як своєрідну модель реального існуючого світу, що формується на поняттєвому рівні й актуалізується в мовному просторі людського досвіду. При цьому структури значень лексем, а також пов'язана із цим типова сполучуваність становлять характерні для англійської мови способи сприйняття явищ об'єктивної дійсності, тобто лексичні значення виступають актом інтерпретації фрагмента світу. Номінативні одиниці досліджуваної мови зберігають визначені знання про дійсність, а їхня організація постає як багаторівнева ієрархія.

Таким чином, лексичний склад англійської мови найбільшою мірою фіксує і формує визначене уявлення про об'єктивний світ, його закони, просторово-часові зв'язки явищ природи і предметів - мовну картину світу, яка $\epsilon$ своєрідною для кожного народу, породжуючи певні культурні стереотипи. Такий культурно зумовлений простір міститься в семантичній сфері, становлячи підгрунтя, на яке накладаються складові системи кожної 3 мов. Пізнаючи навколишній світ, людина намагається визначити цінність предметів, явищ, законів природи та суспільства, своє місце у світі.

Метою дослідження є розкриття семантичних особливостей лексикосемантичної групи «Добро» в сучасній англійській мові з урахуванням іï системно-структурної організації. Таке комплексне дослідження є безперечно актуальним, оскільки вивчення засобів вербалізації добра в мовній картині світу англійців із точки зору системності дає нове осмислення лінгвістичних подій.

\section{Методологія та матеріал дослідження.}

Матеріалом дослідження слугували 411 іменників на позначення добра в англійській мові, у формулах тлумачення яких було виділено 1147 лексичних значень, відібрані внаслідок суцільного аналізу найавторитетнішого тлумачного словника англійської мови [15]. 
Для збору, класифікації мовного матеріалу та комплексного дослідження системно-структурних особливостей лексико-семантичної групи «Добро» в сучасній англійській мові використовуємо методику формалізованого аналізу лексичної семантики, одним із положень якої $\epsilon$ введення формального, суто мовного критерію - віднесеності слів, які аналізуються, до однієї частини мови - іменника, що успішно апробовано професором М.П. Фабіан при дослідженні етикетної лексики в українській, англійській та угорській мовах [14, с. 19]. Ця методика дає змогу вивчити й формалізовано описати семантику слів, які позначають добро у досліджуваній мові за допомогою матричного способу представлення семантичних відношень між словами, а матрицю (див. табл.1) - як модель семантичних зв'язків з одного боку та семантичної структури лексики 3 іншого.

Таблиця 1

Фрагмент матриці на позначення добра в англійській мові

\begin{tabular}{|c|c|c|c|c|c|c|c|c|c|c|c|c|c|}
\hline $\begin{array}{l}\text { Лексичний } \\
\text { склад }\end{array}$ & 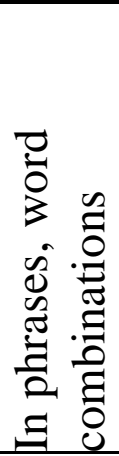 & 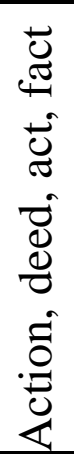 & 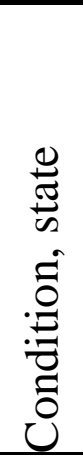 & 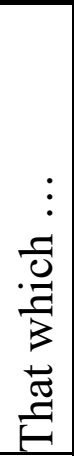 & 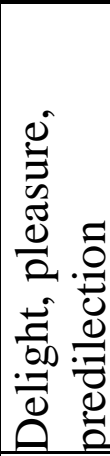 & 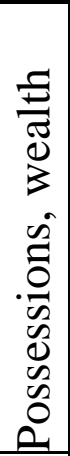 & 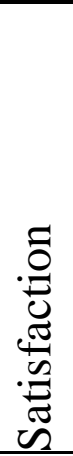 & 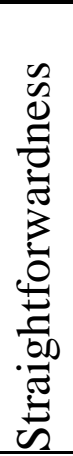 & 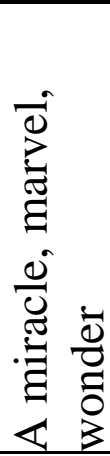 & 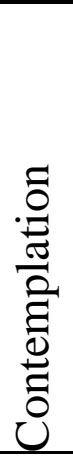 & 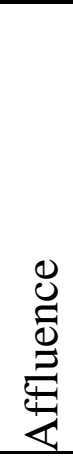 & 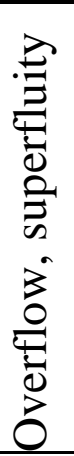 & 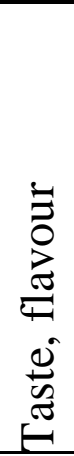 \\
\hline Enjoyment & $\diamond$ & $\nabla$ & $\diamond$ & $\diamond$ & $\diamond$ & $\nabla$ & & & & & & & \\
\hline Acquiescence & $\diamond$ & $\nabla$ & $\Delta$ & & & & $\nabla$ & $\nabla$ & & & & & \\
\hline Admiration & $\diamond$ & $\diamond$ & & $\nabla$ & & & & & $\diamond$ & $\nabla$ & & & \\
\hline Abundance & $\diamond$ & & 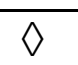 & & & $\diamond$ & & & & & $\nabla$ & $\nabla$ & \\
\hline Zest & $\nabla$ & & & & $\diamond$ & & & & & & & & $\diamond$ \\
\hline
\end{tabular}

Ця модель фіксує семантичні відношення між лексичними одиницями на позначення добра у вигляді стовпчиків та рядків однакової довжини, де знаком (») представлено співвідношення слів та їхніх значень. У ній однаково важливими є як заповнені, так і незаповнені ділянки.

\section{Виклад основного матеріалу дослідження.}

Лексика на позначення добра в сучасній англійській мові нараховує 411 іменників. Досліджувані лексичні одиниці характеризуються різним ступенем полісемії, на підставі чого весь мовний матеріал ділимо на 4 групи: від найбільш полісемічних до моносемічних (див. табл. 2). 
Лексика на позначення добра в англійській мові

\begin{tabular}{|c|c|c|c|c|}
\hline Група & \multicolumn{2}{|c|}{ Лексичні одинищі } & $\begin{array}{c}\text { Кількість } \\
\text { значень }\end{array}$ & Ступінь полісемї \\
\hline I & 84 & $20,4 \%$ & $58-20$ & найвищий \\
\hline II & 110 & $26,8 \%$ & $19-12$ & середній \\
\hline III & 217 & $51,3 \%$ & $11-2$ & низький \\
\hline IV & 6 & $1,5 \%$ & 1 & моносемічні \\
\hline Усього: & 411 & $100 \%$ & & \\
\hline
\end{tabular}

Перша група іменників на позначення добра в англійській мові об'єднує 84 іменники $(20,4 \quad \%$ усього мовного матеріалу), які характеризуються найвищим ступенем полісемії й мають 58-20 значень. Досліджувані лексичні одиниці займають найзаповненіші ділянки матриці. Вони трактують добро як найвищу суспільну та моральну цінність (truth, will, morality, honesty, freedom, dignity), прихильне, люб'язне, уважне ставлення до інших (service, heart, favour, passion, will, interest, charity, pity, devotion, consideration, regard, respect, affection, kindness, care, grace, countenance), суспільне становище особи та іiі визнання (interest, countenance, advantage, kindness, regard, honour, respect, pride, consideration, glory, credit), позитивні емоції та почуття (heart, respect, pride, comfort, passion, will, interest, love, spleen, delicacy, relief, jollity, ease, security), бажання, наміри, прагнення (device, passion, will, glory, pleasure), здобуток, досягнення, звершення (advantage, improvement, jollity) тощо. Іменники service, grace, truth, pride, love, devotion, fortune, spirit, ghost, charity, heaven відображають символічні асоціації, пов'язані з релігійним життям англійців.

Під добром англійці розуміють риси людського характеру та чесноти (grace, truth, heart, favour, honour, propriety, virtue, morality, perfection, spleen, consideration, delicacy, jollity, glory, honesty, courage, freedom, credit, gentility), інтелект, розумові здібності (heart, spirit, gift, kindness), знання, досвід, уміння (return, civility), стремління наблизитися до ідеалу, абсолюту (perfection, improvement), перевагу (service, favour, virtue, advantage, kindness, odds, privilege, convenience), все те, що приносить задоволення, насолоду, створює комфортні умови для життя та безпеку (comfort, easement, convenience, entertainment, crack, security, crack), перевагу, вигоду, користь (service, advantage, privilege, advance, return, interest, use, boot, odds, gift, gratuity, satisfaction, frame, start). 
110 англійських іменників із середнім ступенем полісемії (26,8 \%), які мають 19-12 значень, утворюють другу групу. Їхня семантика характеризується відображенням позитивних рис характеру людини та достоїнств (worth, excellence, dainty, fineness, generosity, paragon, marit, gaiety, tenderness), ïi внутрішнього світу (sympathy, cheer, concern, felicity, glee, rapture, warmth, happiness), вчинків на благо інших (good, exploit, feat, alms). Іменники accident, luck, opportunity, event розкривають вплив певних станів, обставин та факторів на реалізацію добра. Останнє відображає об'єктивну дійсність у формі досягнення вищого рангу в суспільстві, високої оцінки вчинків і суспільної діяльності (eminence, praise, reputation, estimation), ставлення до інших (liking, indulgence), привабливого, здорового зовнішнього вигляду (health, beauty), надій, мрій та можливостей (hope, opportunity), матеріальної вигоди (profit, benefit, revenue) та благ (sum, weal, possession, welfare). Досліджувані слова в матриці передають також суспільні норми поведінки (humanity, fairness, chivalry, rightness, decorum, courtesy, elegance), загальнолюдські цінності (peace, wisdom, decency, trust), переваги (preference, reward, partiality, bounty), мирні, дружні стосунки (agreement, friendship), поняття духовної сфери особистості (doom, providence, divinity, deity, salvation).

Лексичні одиниці 3 низьким ступенем полісемії розташовуються приблизно посередині матриці, виступаючи перехідною зоною, і служать для зв'язку багатозначних іменників із моносемічними. В сучасній англійській мові 217 слів із низьким ступенем полісемії (11-2 значень) об'єднуються в одну групу, яка складає 51,3 \% усього мовного матеріалу. Серед характерних ознак іменників на позначення добра з низьким ступенем полісемії особливо виділяються дії, направлені на підтримку, сприяння, допомогу (aid, backing, succor, helping, auspices, benefaction, donation, supporting, rescue), благородні вчинки, варті поваги (valour, heroism), характерні риси особистості (comeliness, hospitality, gentleness, righteousness, acquiescence, valour, sincerity, prowess, nobleness, goodliness, gracefulness, nobility), прихильне, уважне, шанобливе, щире ставлення до людини (goodwill, homage, admiration, heed, adoration), iï досягнення, здобутки, звершення (accomplishment, advancement, furtherance, achievement, gain, acquirement), суспільне визнання (renown, esteem, noblesse, respectability), перевагу (preferment, prerogative, immunity, bonus, dominance) та користь (behoof, avail, usefulness). Досліджувані іменники характеризуються широким діапазоном вираження позитивних емоцій та почуттів (solace, elation, enjoyment, zest, compassion). Семантика веселощів, розваг розкривається за допомогою лексем frolic, respite, remedy, fun, merriment, exultation, jubilation, revelry.

Лексичні одиниці цієї групи вказують на матеріальні цінності та особистісний комфорт (proceed, plenty, treasure, chattel, holding, content, commonwealth, belonging, luxury, merchandise, propensity, affluence, ware, 
money, abundance). Добро в розумінні англійців - це непередбачувані, дивовижні події, визначені долею заздалегідь, які приносять щастя, успіх, задоволення (lottery, dime, fortuity, windfall, miracle, marvel). Релігія значною мірою вплинула на формування уявлень про добро англійським народом, про що свідчить наявність численних слів, які стосуються релігійних законів, норм, метафоричних понять, символічних образів: piety, sanctity, purity, angel, paradise, God. Слова цієї групи відображають суб' єкта доброго вчинку (good-doer, aider, benefactor, friend, comforter), суспільну норму та ввічливу поведінку (uprightness, properness, chastity, politeness, probity), відплату за певні вчинки (retaliation, thankfulness).

6 англійських моносемічних слів (1,5\%) утворюють четверту групу. Англійці трактують добро як добре божество або дух (agathodemon), задоволення, втіху (delighting), суспільне благо (common good), удачу, везіння (goodhap), приємність, поблажливість, сердечність, щирість, задушевність; сердечну прихильність або дружнє почуття до інших; щиру та дружелюбну манеру (pleasantness (leniency, cordiality)). Цікавою $\epsilon$ семантика іменника behalf, яка розкривається на фоні виразів та словосполучень, що виступає розрізнювальною ознакою цієї лексичної одиниці в межах досліджуваної групи, адже, набуваючи нових відтінків значень у сполученні 3 іншими частинами мови, вона семантично пов'язується 3 іншими одиницями лексико-семантичної групи «Добро». Характерними для неї є вирази in behalf of - для, заради; на користь; на захист; to speak / to plead in behalf of smb's case - захищати когось; on behalf of - від імені (когось); in his behalf - у його інтересах.

Комплексне дослідження іменників на позначення добра в сучасній англійській мові підтвердило, що найбільш важливі для свідомості ціннісні поняття активно вербалізуються та знаходять багаточисленні способи лексикалізації у мовній картині світу англійців. Вивчення тенденцій у духовно-культурних цінностях і ціннісних орієнтаціях англійського етносу дало змогу проникнути в глибинні процеси, що відбуваються в суспільнополітичному, економічному й культурному житті суспільства, що є важливим для побудови картини світу.

\section{Висновки і перспективи дослідження.}

Семантичний аналіз слів на позначення добра в сучасній англійській мові показав, що за словниковими, системними значеннями слів стоїть глибокий вміст неексплікованої інформації, яка безпосередньо пов'язана 3 взаємодією особи з середовищем, досвідом і специфікою іiі пізнавальної активності, спрямованої на взаємодію 3 оточуючою дійсністю. Добро в свідомості англійців об'єктивується як предмет, особа, іiі риси характеру, внутрішній світ, моральні цінності, положення у суспільстві, діяльність, соціальна орієнтація та соціальна активність, оцінка навколишнього світу, 
ставлення до реальності, до інших осіб, вияв різноманітних почуттів, стосунки між людьми, родинні зв'язки, соціальні потреби, а також норма поведінки. Значне місце в цій системі посідає відображення світогляду і світовідчуття людей, засноване на вірі в існування Бога, біблійні та міфологічні уявлення.

Побудована матриця лексико-семантичної групи «Добро» дала можливість розглядати досліджуваний лексичний склад як системне утворення, що має визначену структуру. Порядок та організація слів у межах досліджуваної лексико-семантичної групи ієрархічні. Досліджувані іменники ділимо на 4 групи, що містять слова 3 високим, середнім, низьким ступенем полісемії та моносемічні.

Перспективним вважаємо дослідження форм та засобів прояву добра в інших як споріднених, так і неспоріднених мовах для виявлення спільних i відмінних механізмів мислення носіїв мови в процесі категоризації та концептуалізації світу.

\section{ЛIТЕРАТУРА}

1. Бондаренко Е. В. Концептуальная модель миропознания человека: методология и парадигматика//Вісник Харківського національного університету ім. В. Н. Каразіна 667 (2005): 86-91.

2. Вежбицкая А. Семантика, культура и познание: общечеловеческие понятия в культурноспецифичных контекстах. М., 1993. 206с.

3. Голубовська I. О. Етнічні особливості мовних картин світу: монографія. Київ: Логос, 2004. 284c.

4. Жайворонок В. В. Українська етнолінгвістика: Нариси. Київ: Довіра, 2007. 262c.

5. Карасик В. И. Оценочная мотивировка, статус лица и словарная личность// Филология 3 (1994): 2-7.

6. Кочерган М. П. Основи зіставного мовознавства. К.: Вид. центр «Академія», 2006. 424c.

7. Кубрякова Е. С. Начальные этапы становления когнитивизма: Лингвистика - психология - когнитивная наука// Bonpocbl языкознания 4 (1994): 34-47.

8. Леви-Стросс К. Первобытное мышление. Москва: Республика, 1994. $384 \mathrm{c}$.

9. Мед Н. Г. «Оиеночная картина мира в испанской лексике $u$ фразеологии (на материале испанской разговорной речи)». Diss. СанктПетербург, 2008. Abstract.

10.Попова 3. Д., Стернин И. А. Очерки по когнитивной лингвистике. Воронеж: Истоки, 2002. 192с.

11.Попова 3. Д., Стернин И. А. Язык и национальная картина мира. Воронеж: ВГУ, 2002. 162c. 
12.Прохоров Ю. Е. К проблеме «концепта» и «концептосферы»// Язык, сознание, коммуникащия 30 (2005): 74-94.

13. Соломаха А. В. Лексика, яка вербалізує етнореалії в сучасній німецькій мові: культурологічний аспект//Сучасні дослідження 3 іноземної філології 3 (2005): 242-251.

14. Фабіан М. П. Етикетна лексика в українській, англійській та угорській мовах. Ужгород: Інформаційно-видавниче агентство «IBA», 1998.256с.

15. Murray James, ed. Oxford English Dictionary. Vol. 1-12. London: Oxford UP, 1963.

16. Wierzbicka A. Cross-Cultural Pragmatics: The Semantics of Human Interaction. Berlin: Mouton de Gruyter, 2003. 501p. 